\title{
The Post-Transplant Neutrophil-to-Lymphocyte Ratio and Platelet-to-Lymphocyte Ratio in Relation to Graft Function among Renal Transplant Recipients
}

\author{
Renal Transplant Alıcılarında Transplant Sonrası Nötrofil-Lenfosit Oranı ve Trombosit-Lenfosit \\ Oranı ile Graft Fonksiyonu Arasındaki İlişki
}

\author{
Emel IŞIKTAŞ SAYILAR ${ }^{1}$ \\ (D) 0000-0002-8824-6560 \\ Sıla ÇELIKK ${ }^{2}$ \\ (D) 0000-0002-5419-8169 \\ Muhammed Emir INCE ${ }^{2}$ \\ (D) 0000-0002-3372-1934 \\ İhsan ERGÜN ${ }^{1}$ \\ (1) 0000-0003-2066-5512
}

\begin{abstract}
Aim: The aim of this study was to evaluate the association of neutrophil-to-lymphocyte ratio (NLR) and platelet-to-lymphocyte ratio (PLR) with acute rejection after kidney transplantation.

Material and Methods: A total of 36 adult renal transplant recipients ( 33 males, 3 females) with a median age of 41 (range, 19-64) years were included in this retrospective study conducted between January 2016 and January 2019. Data on patient demographics and laboratory findings (neutrophil, lymphocyte, platelet, creatinine, eGFR, serum uric acid and $\mathrm{C}$-reactive protein) were recorded. Acute rejection was defined via renal biopsy in accordance with Banff criteria.

Results: Acute rejection occurred in 16 (44.4\%) patients. NLR (median 3.75 vs. 1.99 , p=0.001) and PLR (median 125.59 vs. $99.23, \mathrm{p}=0.008$ ) values were significantly higher in the acute rejection group than in the control group. Area under the curve was calculated to be 0.822 for NLR and to be 0.759 for PLR. Cut-off values were determined to be $>2.5$ ( $75 \%$ sensitivity and $75 \%$ specificity) for NLR and to be $>108$ ( $81 \%$ sensitivity and $65 \%$ specificity) for PLR. Univariate analysis revealed a strong correlation of acute rejection both with NLR $>2.5$ (Odds Ratio $(\mathrm{OR})=0.267,95 \%$ Confidence Interval $(\mathrm{CI})=0.089-0.803, \mathrm{p}=0.019)$ and PLR $>108$ $(\mathrm{OR}=0.231,95 \% \mathrm{CI}=0.066-0.810, \mathrm{p}=0.022)$.

Conclusion: In kidney transplant patients, there is a strong relationship between high NLR and PLR values and the development of acute rejection. As simple, easy-to-access, inexpensive and non-invasive methods, PLR, and particularly NLR, may be potential tests to diagnose posttransplant acute rejection.

Keywords: Kidney transplantation; neutrophil-to-lymphocyte ratio; platelet-to-lymphocyte ratio; acute rejection.
\end{abstract}

ÖZ

Amaç: Bu çalışmanın amacı nötrofil-lenfosit oranı (NLO) ve trombosit-lenfosit oranı (TLO) ile böbrek nakli sonrası akut rejeksiyon arasındaki ilişkiyi değerlendirmektir.

Gereç ve Yöntemler: Ocak 2016 ile Ocak 2019 tarihleri arasında yürütülen bu geriye dönük çalışmaya ortanca yaşı 41 (aralık, 19-64) yıl olan toplam 36 yetişkin (33 erkek, 3 kadın) böbrek nakli alıcısı dahil edildi. Hastaların demografik özellikleri ve laboratuvar bulguları (nötrofil, lenfosit, trombosit, kreatinin, eGFR, serum ürik asit, C-reaktif protein) kaydedildi. Akut rejeksiyon Banff kriterlerine göre renal biyopsi ile tanımlandı.

Bulgular: On altı $(\% 44,4)$ hastada akut rejeksiyon gelişti. NLO (ortanca 3,75'e karşı 1,99; $\mathrm{p}=0,001$ ) ve TLO (ortanca 125,59'a karş1 99,23; $\mathrm{p}=0,008$ ) değerleri akut rejeksiyon grubunda kontrol grubuna göre anlamlı olarak daha yüksekti. Eğri altındaki alan, NLO için 0,822 ve TLO için 0,759 olarak hesapland. Cut-off değer NLO için $>2,5$ (\%75 duyarlılık ve \%75 özgüllük) ve TLO için $>108$ (\%81 duyarlılık ve \%65 özgüllük) olarak belirlendi. Tek değişkenli analiz, NLO >2,5 (Odds Ratio $(\mathrm{OR})=0,267$; \%95 Güven Aralığ $(\mathrm{GA})=0,089-0,803$; $\mathrm{p}=0,019)$ ve TLO >108 (OR=0,231;\%95 $\mathrm{GA}=0,066-0,810 ; \mathrm{p}=0,022)$ ile akut rejeksiyon arasında güçlü bir korelasyon olduğunu ortaya koydu.

Sonuç: Böbrek nakli hastalarında, yüksek NLO ve TLO değerleri ile akut rejeksiyon gelişimi arasında güçlü bir ilişki vardır. Basit, erişimi kolay, ucuz ve invaziv olmayan yöntemler olarak TLO ve özellikle NLO, transplant sonrası akut rejeksiyonu teşhis etmek için potansiyel testler olabilirler.

Anahtar kelimeler: Böbrek nakli; nötrofil-lenfosit oranı; trombosit-lenfosit oranı; akut rejeksiyon. 


\section{INTRODUCTION}

Although kidney transplantation is the most effective treatment option in the management of end-stage renal disease, the graft function loss and acute rejection (AR) are the major complications in the post-transplant period (1). Donor type, tissue adaptation, age, gender, primary diagnosis, delayed graft function, infections and vascular complications are amongst the several factors considered to be related to AR. Despite the improved success of immunosuppressive therapy in recent years, graft loss becomes inevitable in some patients $(2,3)$.

While the needle biopsy is considered the standard approach in diagnosis of acute allograft rejection, it is an invasive method with potential complications such as hemorrhage, infection and graft loss.

Non-invasive methods in diagnosing AR have become increasingly used such as serum and urine biomarkers along with cytometric and PCR analyses. However, due to limitations of the currently available methods in terms of sensitivity, specificity, predictive value, accessibility and cost issues, the search for ideal test and methods continues (2). The neutrophil-to-lymphocyte ratio (NLR) and platelet-tolymphocyte ratio (PLR) are considered strong predictors of inflammation and to be associated with worse prognosis in a variety of conditions that include chronic kidney disease (3), cancer (4), coronary artery disease (5), rheumatic diseases (6), heart transplantation (7) and kidney transplantation (8-10). Given the inflammatory nature of the rejection process, we have hypothesized that NLR and PLR may alter during the rejection process and in this way; they may serve as easily accessed, inexpensive and non-invasive methods of detecting AR.

Therefore, the objective of this study was to investigate post-transplant NLR and PLR in relation to acute graft rejection in renal transplants recipients.

\section{MATERIAL AND METHODS}

This retrospective single-center study enrolled 54 consecutive patients over 18 years of age who underwent kidney transplantation between January 2016 and January 2019 and were followed up in the transplantation clinic. Written informed consent was obtained from each subject following a detailed explanation of the objectives and protocol of the study which was conducted in accordance with the ethical principles stated in the "Declaration of Helsinki" and approved by the Ufuk University Faculty of Medicine Ethics Committee (25.02.2020, 4). Data on patient demographics, clinical and laboratory findings and follow-up records were retrieved from the hospital database. Patients receiving ABO-compatible kidney transplantation for the first time were included in the study. Age of $<18$ years, prior history of transplantation, presence of postoperative vascular complications, administration of a steroid-free immunosuppressive treatment protocol (steroids increase neutrophils and decrease lymphocytes, thus modifying both NLR and PLR), any proven history of acute coronary syndrome, cancer, primary bone marrow disorder, thrombocytopenia, thrombocytosis, active autoimmune disease, active chronic inflammation due to untreated chronic infections, any diagnosis of BK nephropathy or CMV positivity, and systemic, urinary or local documented infection proven by a culture at any evaluation period were the exclusion criteria of the study.
Routine laboratory tests included complete blood count (neutrophil, lymphocyte, and platelet), creatinine, serum uric acid, C-reactive protein (CRP) and tacrolimus levels as well as estimated glomerular filtration rate (eGFR) measurement. The patients were not evaluated in the early post-transplant period to rule out the potential impact of surgery or high dose immunosuppression on white blood cells.

When indicated, anti-thymocyte globulin (ATG, Grafalon Neovii) was administered at $100 \mathrm{mg} / \mathrm{g}$ dose for 3 days. Following total $1500 \mathrm{mg}$ intravenous methylprednisolone, all patients received oral prednisolone $(0.8$ $\mathrm{mg} / \mathrm{kg} /$ day). Prednisolone dose was tapered to $30 \mathrm{mg} /$ day at $1 \mathrm{month}$, to $20 \mathrm{mg} /$ day at 2 months and to $5 \mathrm{mg} /$ day after 3 months. In the maintenance treatment phase, calcineurin inhibitor (tacrolimus (Tac); $0.1 \mathrm{mg} / \mathrm{kg} /$ day, 2 doses per day) and antiproliferative agent (mycophenolate mofetil; maximum $2 \mathrm{~g}$ /day or mycophenolate sodium; maximum $1440 \mathrm{mg} / \mathrm{g}$ ) were used along with the prednisolone. Tac doses were titrated as needed to achieve target blood levels. AR was defined as the increase in creatinine levels by $30 \%$ above the baseline values that was not attributable to any other causes, and in case of AR, renal biopsy was performed and treatment (pulse methyl-prednisolone, ATG, plasmapheresis, and intravenous immunoglobulin treatments alone or in combination) were administered according to Banff criteria (11).

Age- and median follow-up time-matched kidney transplant patients who had no rejection episode served as the control group. The blood samples collected on the day of the admission to the clinic were used for the analyses in the AR group, while blood samples collected on the last outpatient clinic visit day were used for the analyses in the control group.

NLR was calculated by dividing the absolute neutrophil count by the absolute lymphocyte count. PLR was calculated by dividing the absolute platelet count by the absolute lymphocyte count. Varying levels of NLR have been considered to be prognostic in different disease settings, including NLR $>5$ in cancer patients and NLR $>3.5$ in cardiovascular and acute surgical patients (10). In general, a normal NLR is considered to be $\leq 3$. A NLR value of 2.5 or greater was therefore considered as elevated in this study.

\section{Statistical Analysis}

Statistical analysis was made using IBM SPSS Statistics for Windows, version 22.0 (IBM Corp., Armonk, NY) package. We could not say that probability distributions of the all variables are normally distributed with Kolmogorov-Smirnov test, therefore Mann-Whitney U test was used for those variables. To estimate the predictive value of NLR and PLR for the AR, receiver operating characteristic (ROC) curve was plotted, and the area under the curve (AUC) was calculated to compare the discriminatory performance of NLR or PLR in prediction of the AR, with $95 \%$ confidence interval (CI). After determining the appropriate cut-off points, with univariate binary logistic regression we further examine the relationship from a categorical perspective. Data were expressed as median, $1^{\text {st }}$ and $3^{\text {rd }}$ quartiles, minimummaximum, and percent where appropriate. A $\mathrm{p}$ value of $<0.05$ was considered statistically significant. 


\section{RESULTS}

The final study group subjected to analysis included 36 patients since 18 patients were excluded due to active infection. Majority of patients $(n=33,91.7 \%)$ were males, the median age was 41 (range, 19-64) years and the followup period was 34.4 (range, 21.3-53.4) months. The primary etiology of end-stage renal disease included chronic glomerulonephritis in $14(38.9 \%)$ patients, hypertension in $7(19.4 \%)$ patients, secondary amyloidosis in $6(16.7 \%)$ patients, type 2 diabetes mellitus in $3(8.3 \%)$ patients, nephrolithiasis in $2(5.6 \%)$ patients and polycystic kidney disease in $2(5.6 \%)$ patients, while no detectable cause was evident in $2(5.6 \%)$ patients.

Data on type of dialysis, tissue adaptation, type of transplantation and type of induction treatments of patients are provided in Table 1.

The median values for neutrophil, lymphocyte and platelets were 5130 (range, 1490-9940), 1890 (range, $1100-3500$ ) and 227450 (range, 124000-308400) cell $/ \mathrm{mm}^{3}$, respectively. The median NLR was 2.40 (range, 1.05-8.02) and PLR was 113.99 (range, 65.26-237.90).

Acute allograft rejection occurred in $16(44.4 \%)$ patients. In microscopic examination of kidney biopsies of patients with AR; tubulitis in 9 patients, peritubular capillaritis in 7 patients, endarteritis in 8 patients, with different densities, were observed. Thrombotic microangiopathy was observed in 2 patients. Amyloid was negative in all patients. In immunohistochemical examination; $\mathrm{T}$ cell infiltrates of different densities were observed with $\mathrm{CD} 3$ in 12 patients. While linear staining was observed in peritubular capillaries diffuse with CD4 in 10 patients, no specific staining was observed in peritubular capillaries with CD4 in 6 patients. SV40 was negative in all patients. In terms of histopathological diagnosis, borderline changes in terms of cellular rejection in 5 patients, acute T-cell mediated rejection in 9 patients (4 patients Banff grade IA, 3 patients Banff Grade IB, 2 patients Banff grade IIA), acute antibody-mediated and acute T-cell mediated rejection (Banff grade IIA) was observed in 2 patients. In addition, findings consistent with calcineurin inhibitor toxicity were observed in 4 patients.

Comparisons of the demographics and clinical features between the AR and control groups are summarized in Table 2. The median duration of follow up was 39.26 (range, 21.47-53.10) months in the AR group and 33.30 (range, 21.33-53.40) months in the control group. In the AR group, the median time from renal transplantation to
AR was 1.72 (range, 0.03-26.30) months. The patients in the AR and control groups were similar in terms of duration of follow-up $(p=0.924)$, age $(p=0.975)$ and uric acid levels $(\mathrm{p}=0.823)$. When compared to control group, patients in the AR group had significantly higher baseline serum creatinine $(\mathrm{p}<0.001)$ and CRP levels $(\mathrm{p}<0.001)$ whereas significantly lower eGFR $(\mathrm{p}<0.001)$.

Table 1. Demographic and clinical characteristics in the overall study group $(n=36)$

\begin{tabular}{lc}
\hline & $\mathbf{n}(\mathbf{\%})$ \\
\hline Gender & $33(91.7)$ \\
Male & $3(8.3)$ \\
Female & \\
Dialysis type & $22(61.1)$ \\
Preemptive & $13(36.1)$ \\
Hemodialysis & $1(2.8)$ \\
Peritoneal dialysis & \\
Transplantation type & $36(100)$ \\
Live & $0(0.0)$ \\
Cadaveric & $3(8.3)$ \\
Mismatch & $1(2.8)$ \\
0 MM & $8(22.2)$ \\
1 MM & $14(38.9)$ \\
2 MM & $4(11.1)$ \\
3 MM & $5(13.9)$ \\
4 MM & $1(2.8)$ \\
5 MM & \\
6 MM & $10(27.8)$ \\
Induction treatment & $26(72.2)$ \\
ATG & Median $\left(\mathbf{Q}_{1}-\mathbf{Q}_{3}\right)[$ Min-Max] \\
Non-inducted &
\end{tabular}

\begin{tabular}{|c|c|}
\hline Age (year) & $41(30-53)[19-64]$ \\
\hline Transplant time (month) & $34.4(28.6-47.2)[21.33-53.40]$ \\
\hline Creatinine (mg/dL) & $1.37(1.25-1.78)$ [0.82-6.49] \\
\hline eGFR & $58(45-68.5)[8.00-108.00]$ \\
\hline Uric acid (mg/dL) & $5.65(5.15-6.45)[3.60-8.00]$ \\
\hline $\mathrm{CRP}(\mathrm{mg} / \mathrm{dL})$ & $1.05(0.25-4)[0.11-90.06]$ \\
\hline Neutrophil (cell/mm³) & $5130(3930-5980)$ [1490-9940] \\
\hline Lymphocyte $\left(\right.$ cell $\left./ \mathrm{mm}^{3}\right)$ & $1890(1710-2340)$ [1100-3500] \\
\hline Platelet $\left(\right.$ cell $\left./ \mathrm{mm}^{3}\right)$ & $227450(201600-254450)[124000-308400]$ \\
\hline NLR & $2.40(1.82-3.29)[1.05-8.02]$ \\
\hline PLR & $113.99(88.44-142.75)$ [65.26-237.90] \\
\hline
\end{tabular}

Table 2. Comparison of demographical characteristic and biochemical parameters in study groups

\begin{tabular}{lccccccc}
\hline & \multicolumn{3}{c}{ Acute Rejection (n=16) } & \multicolumn{3}{c}{ Control (n=20) } & p \\
\cline { 2 - 6 } & Median & $\mathbf{Q}_{1}-\mathbf{Q}_{\mathbf{3}}$ & Min-Max & Median & $\mathbf{Q}_{\mathbf{1}}-\mathbf{Q}_{\mathbf{3}}$ & Min-Max & \\
\hline Duration follow-up (month) & 39.26 & $27.86-48.80$ & $21.47-53.10$ & 33.30 & $29.64-44.99$ & $21.33-53.40$ & 0.924 \\
Age (year) & 44.00 & $26.75-54.25$ & $19-61$ & 38.50 & $30.00-49.75$ & $24-64$ & 0.975 \\
Creatinine (mg/dL) & 1.76 & $1.53-3.15$ & $1.34-6.49$ & 1.27 & $1.12-1.37$ & $0.82-1.70$ & $<\mathbf{0 . 0 0 1}$ \\
eGFR & 44.00 & $23.75-53.02$ & $8.0-66.00$ & 66.71 & $62.25-77.00$ & $43.00-108.00$ & $<\mathbf{0 . 0 0 1}$ \\
Uric acid (mg/dL) & 5.55 & $5.20-6.52$ & $3.70-8.00$ & 5.70 & $5.05-6.40$ & $3.60-7.70$ & 0.823 \\
CRP (mg/L) & 1.70 & $1.10-7.97$ & $0.50-9.06$ & 0.35 & $0.08-1.62$ & $0.01-8.50$ & $<\mathbf{0 . 0 0 1}$ \\
NLR & 3.75 & $2.49-5.07$ & $1.31-8.02$ & 1.99 & $1.60-2.47$ & $1.05-3.08$ & $<\mathbf{0 . 0 0 1}$ \\
PLR & 125.59 & $112.97-162.79$ & $71.88-237.90$ & 99.23 & $83.09-120.31$ & $65.26-146.93$ & $\mathbf{0 . 0 0 8}$ \\
\hline eGFR: estimated glomerular filtration rate, CRP: C-reactive protein, NLR: neutrophil-to-lymphocyte ratio, PLR: platelet-to-lymphocyte ratio, Q1-03: 1st quartile- 3rd quartile, Min-Max: minimum-maximum
\end{tabular}


Both NLR (median 3.75 vs. 1.99, p<0.001) and PLR (median 125.59 vs. 99.23, $\mathrm{p}=0.008$ ) values were significantly higher in the AR group compared to control group (Table 2, Figure 1, Figure 2).

ROC analysis revealed NLR cut-off value $>2.5$ (AUC $=0.822, \quad 95 \% \quad \mathrm{CI}=0.677-0.967, \quad$ standard error $(\mathrm{SE})=0.074, \mathrm{p}=0.019)$ to be a potential marker of AR with a sensitivity of $75 \%$ and specificity of $75 \%$, while PLR cutoff value $>108 \quad$ (AUC $=0.759,95 \% \quad \mathrm{CI}=0.597-0.922$, $\mathrm{SE}=0.083, \mathrm{p}=0.022$ ) was also a potential marker of $\mathrm{AR}$ with a sensitivity of $81 \%$ and specificity of $65 \%$. In this regard, values of NLR>2.5 and PLR>108 were considered as elevated (Figure 3 ).

Univariate binary logistic regression analysis was performed to analyze the association of both NLR and PLR with AR. The NLR >2.5 (Odds Ratio $(\mathrm{OR})=0.267$, 95\% CI=0.089-0.803, $\mathrm{p}=0.019)$ and PLR $>108(\mathrm{OR}=0.231$, $95 \% \mathrm{CI}=0.066-0.810, \mathrm{p}=0.022$ ) were determined to be significantly associated with AR.

\section{DISCUSSION}

Our findings revealed significantly higher NLR and PLR values in the AR group when compared to control group, as well as the association of higher NLR and PLR values with an increased risk of AR in renal transplant recipients. NLR and PLR are inflammatory markers that are inexpensive and readily available in routine clinical practice. Growing evidence exists regarding the predictive value of these markers in several conditions such as cancer, cardiovascular disease, rheumatic diseases, infections and transplantations (7,12-17). Additionally there are studies showing that NLR and PLR levels are positively correlated with inflammatory cytokines in patients with end-stage renal disease (15). Turkmen et al. (14) reported that kidney transplant patients had a higher NLR than healthy subjects and concluded that the higher values were due to the ongoing inflammation in these patients (14).

AR is the major cause of graft dysfunction in kidney transplantation. Given that most of the patients who developed AR are initially asymptomatic, the diagnosis can often be delayed. Therefore, availability of an easily applicable marker for both prediction and early detection of AR is important for kidney transplant patients. The most frequently used parameter for AR prediction is the increase in serum creatinine, but the increase in creatinine is a reflection of the histological damage in the kidney in the late period of the rejection episode.

The mechanisms underlying the association of elevated NLR and PLR with the development of AR are considered complex and unclear. Inflammation-related disruptions in hematologic cell lines including neutrophilia and thrombocytosis lead to elevations of NLR and PLR. However, most of immunosuppressive treatments selectively inhibit the activation and proliferation of lymphocytes. In this regard, the combination of either neutrophilia or thrombocytosis with lymphopenia may contribute to development of AR. Several experimental studies in mice have indicated the possible role of neutrophils after transplantation, mainly via neutrophil activated $\beta 2$-integrin, while the association of neutrophil penetration and gathering in the allograft tissue with AR has been reported to occur through $\beta 2$-integrin in rodents.
Neutrophils are known to induce the progression of AR of allografts and thus the inhibition of neutrophil infiltration into the allograft has been associated with lower likelihood of rejection and an improved survival of the allograft. In this regard, NLR is considered amongst the independent predictors of the risk of AR (18-20).

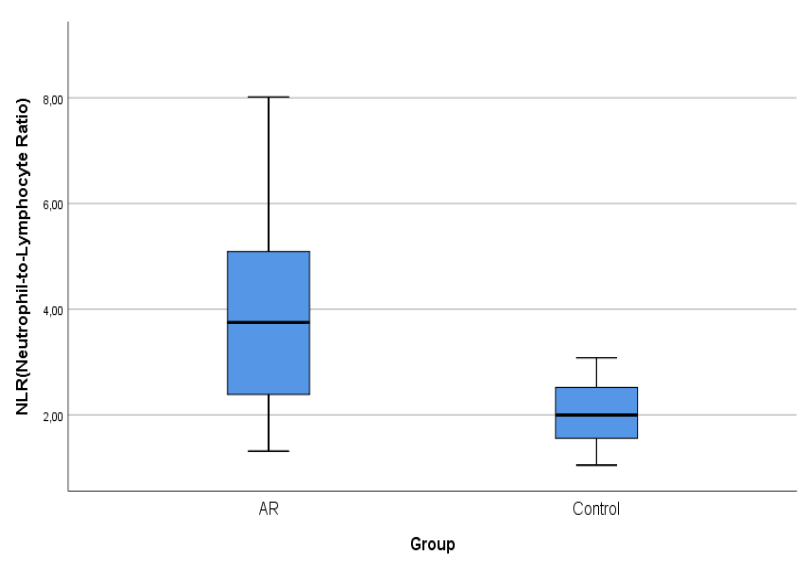

Figure 1. Comparison of NLR values between acute kidney rejection and control groups: the median NLR level was significantly higher in AR group (3.75 vs 1.99, $\mathrm{p}<0.001$ ).

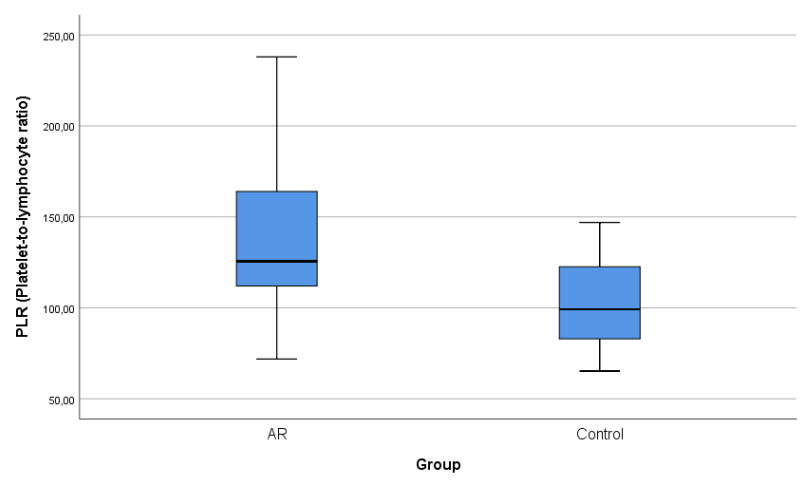

Figure 2. Comparison of PLR values between acute kidney rejection and control groups: the median PLR level was significantly higher in AR group (125.59 vs 99.23, $\mathrm{p}=0.008)$.

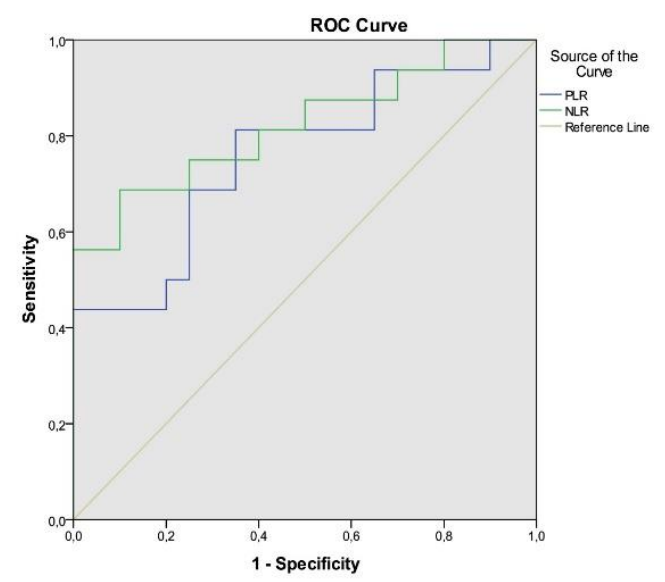

Figure 3. ROC curve analysis of the role of NLR and PLR in prediction of acute rejection. ROC: receiver operating characteristic, NLR: neutrophil-to-lymphocyte ratio, PLR: platelet-to-lymphocyte ratio 
Ergin et al. (16) reported that NLR values $>2.5$ were associated with AR (median NLR 4.06 vs. 1.24) in kidney transplant patients. In a study investigating early allograft rejection and NLR rate in 1531 liver transplant patients, the NLR rate was found to be significantly higher in patients with rejection (median 3.49 vs. 2.07) and NLR $\geq 2,85(\mathrm{OR}=1.89)$ was an independent predictor of early allograft rejection (21). Similar results were obtained in our study (median NLR 3.75 vs 1.99). In addition, we believe that the increase in NLR in AR patients was unrelated to corticosteroid dosage, because all the patients were using the same maintenance dosage.

In our study, the risk of developing AR in patients with an NLR value below 2.5 was 0.267 times lower than in patients with an NLR value above 2.5. Interestingly, Naranjo et al. (1) indicated 7-fold higher NLR in patients without evidence of acute cellular rejection than in patients with findings of acute cellular rejection, and similar trend (5.5-fold higher levels in the absence of rejection) was also reported for PLR and they explained this different result with the relative increase of lymphocyte count in patients who developed rejection (1).

Halazun et al. (10) reported the association of elevated preoperative NLR levels with a higher risk of developing graft function along with role of NLR over 3.5 in predicting $(\mathrm{AUC}=0.751)$ the delayed graft function. However in our study, patients with NLR over 2.5 were more likely to develop AR (AUC=0.822).

Turkmen et al. (22) reported that PLR can be used to predict inflammation in patients with end stage renal disease and it is superior to NLR when used as a marker of inflammation. Seropian et al. (7) reported that in heart transplant patients, NLR was a more useful marker than PLR at ROC analysis (AUC, 0.644 vs. 0.599) in prediction of 1-year mortality after transplantation. In the current head-to-head comparison of NLR and PLR, our findings revealed that NLR was more useful marker at ROC curve for predicting AR.

The main limitation of this study is that it was a retrospective single center study. In addition, the sample size was relatively small, and a single measurement of NLR and PLR may not accurately reflect the changes over time. Future studies that obtain serial changes of NLR and PLR would be useful to clarify to role of these ratios in the follow up of AR.

\section{CONCLUSION}

In conclusion, our findings indicate that PLR and specially NLR are non-invasive, useful, low-cost, widely available markers for $A R$ in renal transplant patients. Further validation from prospective larger-scale controlled and multicenter cohorts seems to be helpful to determine the predictability of these tests in the early diagnosis of AR.

Ethics Committee Approval: The study was approved by the Ethics Committee of Ufuk University Faculty of Medicine (25.02.2020, 4).

Conflict of Interest: None declared by the authors.

Financial Disclosure: None declared by the authors.

Acknowledgements: None declared by the authors.

\section{REFERENCES}

1. Naranjo M, Agrawal A, Goyal A, Rangaswami J. Neutrophil-to-lymphocyte ratio and platelet-tolymphocyte ratio predict acute cellular rejection in the kidney allograft. Ann Transplant. 2018;23:467-74.

2. Strom TB, Suthanthiran M. Prospects and applicability of molecular diagnosis of allograft rejection. Semin Nephrol. 2000;20(2):103-7.

3. Altunoren O, Akkus G, Sezal DT, Ciftcioglu M, Guzel FB, Isiktas S, et al. Does neutrophyl to lymphocyte ratio really predict chronic kidney disease progression? Int Urol Nephrol. 2019;51(1):129-37.

4. Guthrie GJ, Charles KA, Roxburgh CS, Horgan PG, McMillan DC, Clarke SJ. The systemic inflammationbased neutrophil-lymphocyte ratio: experience in patients with cancer. Crit Rev Oncol Hematol. 2013;88(1):218-30.

5. Papa A, Emdin M, Passino C, Michelassi C, Battaglia D, Cocci F. Predictive value of elevated neutrophillymphocyte ratio on cardiac mortality in patients with stable coronary artery disease. Clin Chim Acta. 2008;395(1-2):27-31.

6. Erre GL, Paliogiannis P, Castagna F, Mangoni AA, Carru C, Passiu G, et al. Meta-analysis of neutrophilto-lymphocyte and platelet-to-lymphocyte ratio in rheumatoid arthritis. Eur J Clin Invest. 2019;49(1):e13037.

7. Seropian IM, Romeo FJ, Pizarro R, Vulcano NO, Posatini RA, Marenchino RG, et al. Neutrophil-tolymphocyte ratio and platelet-to-lymphocyte ratio as predictors of survival after heart transplantation. ESC Heart Fail. 2018;5(1):149-56.

8. Hogendorf P, Suska A, Skulimowski A, Rut J, Grochowska M, Wencel A, et al. Neutrophillymphocyte ratio and creatinine reduction ratio predict good early graft function among adult cadaveric donor renal transplant recipients. Single institution series. Pol Przegl Chir. 2018;90(2):28-33.

9. Cankaya E, Bilen Y, Keles M, Uyanik A, Bilen N, Aydinli B. Neutrophil-lymphocyte ratio is significantly decreased in preemptive renal transplant patients. Transplant Proc. 2015;47(5):1364-8.

10. Halazun KJ, Marangoni G, Hakeem A, Fraser SM, Farid SG, Ahmad N. Elevated preoperative recipient neutrophil-lymphocyte ratio is associated with delayed graft function following kidney transplantation. Transplant Proc. 2013;45(9):3254-7.

11. Solez K, Colvin RB, Racusen LC, Haas M, Sis B, Mengel M, et al. Banff 07 classification of renal allograft pathology: updates and future directions. Am J Transplant. 2008;8(4):753-60.

12. Ohtaka M, Kawahara T, Takamoto D, Mochizuki T, Ishida H, Hattori Y, et al. Neutrophil-to-lymphocyte ratio in renal transplant patients. Exp Clin Transplant. 2018;16(5):546-49.

13. Kazimoglu H, Uysal E, Dokur M, Gunerkan HR. Evaluation of the relationship between neutrophil lymphocyte ratio and the most common bacterial urinary tract infections after transplantation. Bratisl Lek Listy. 2019;120(2):161-5.

14. Turkmen K, Erdur FM, Guney I, Ozbiner H, Toker A, Gaipov A, et al. Relationship between plasma pentraxin-3, neutrophil-to-lymphocyte ratio, and 
atherosclerosis in renal transplant patients. Cardiorenal Med. 2012;2(4):298-307.

15. Turkmen K, Guney I, Yerlikaya FH, Tonbul HZ. The relationship between neutrophil-to-lymphocyte ratio and inflammation in end-stage renal disease patients. Ren Fail. 2012;34(2):155-9.

16. Ergin G, Deger SM, Kopru B, Derici U, Arinsoy T. High neutrophil-to-lymphocyte ratio predicts acute allograft rejection in kidney transplantation: a retrospective study. Turk J Med Sci. 2019;49(2):52530.

17. Gasparyan AY, Ayvazyan L, Mukanova U, Yessirkepov M, Kitas GD. The platelet-to-lymphocyte ratio as an inflammatory marker in rheumatic diseases. Ann Lab Med. 2019;39(4):345-57.

18. Gabay C, Kushner I. Acute-phase proteins and other systemic responses to inflammation. N Engl J Med. 1999;340(6):448-54.
19. Choi DH, Kobayashi Y, Nishi T, Luikart H, Dimbil S, Kobashigawa J, et al. Change in lymphocyte to neutrophil ratio predicts acute rejection after heart transplantation. Int J Cardiol. 2018;251:58-64.

20. El-Sawy T, Belperio JA, Strieter RM, Remick DG, Fairchild RL. Inhibition of polymorphonuclear leukocyte-mediated graft damage synergizes with short-term costimulatory blockade to prevent cardiac allograft rejection. Circulation. 2005;112(3):320-31.

21. Kwon HM, Moon YJ, Jung KW, Park YS, Jun IG, Kim SO, et al. Neutrophil-to-lymphocyte ratio is a predictor of early graft dysfunction following living donor liver transplantation. Liver Int. 2019;39(8):1545-56.

22. Turkmen K, Erdur FM, Ozcicek F, Ozcicek A, Akbas EM, Ozbicer A, et al. Platelet-to-lymphocyte ratio better predicts inflammation than neutrophil-tolymphocyte ratio in end-stage renal disease patients. Hemodial Int. 2013;17(3):391-6. 